\title{
Phosphatidylinositol 4,5-Bisphosphate Modifies Tubulin Participation in Phospholipase $\mathbf{C} \boldsymbol{\beta}_{1}$ Signaling
}

\author{
Juliana S. Popova, ${ }^{1}$ Arin K. Greene, ${ }^{1}$ Jia Wang, ${ }^{1}$ and Mark M. Rasenick ${ }^{1,2}$ \\ Departments of ${ }^{1}$ Physiology and Biophysics and ${ }^{2}$ Psychiatry, University of Illinois at Chicago, College of Medicine, \\ Chicago, Illinois 60612-7342
}

Tubulin forms the microtubule and regulates certain G-proteinmediated signaling pathways. Both functions rely on the GTPbinding properties of tubulin. Signal transduction through $\mathrm{G} \alpha \mathrm{q}-$ regulated phospholipase $\mathrm{C} \beta_{1}\left(\mathrm{PLC} \beta_{1}\right)$ is activated by tubulin through a direct transfer of GTP from tubulin to $\mathrm{G} \alpha \mathrm{q}$. However, at high tubulin concentrations, inhibition of $\mathrm{PLC} \beta_{1}$ is observed. This report demonstrates that tubulin inhibits $P L C \beta_{1}$ by binding the PLC $\beta_{1}$ substrate phosphatidylinositol 4,5-bisphosphate $\left(\mathrm{PIP}_{2}\right)$. Tubulin binding of $\mathrm{PIP}_{2}$ was specific, because $\mathrm{PIP}_{2}$ but not phosphatidylinositol 3,4,5-trisphosphate, phosphatidylinositol 3-phosphate, phosphatidylinositol, phosphatidylcholine, phosphatidylethanolamine, or inositol 1,4,5-trisphosphate inhibited microtubule assembly. PIP $_{2}$ did not affect GTP binding or GTP hydrolysis by tubulin. Muscarinic agonists promoted microtubule depolymerization and translocation of tubulin to the plasma membrane. $\mathrm{PIP}_{2}$ augmented this process in both Sf9 cells, containing a recombinant PLC $\beta_{1}$ pathway, and SK$\mathrm{N}-\mathrm{SH}$ neuroblastoma cells. Colocalization of tubulin and $\mathrm{PIP}_{2}$ at the plasma membrane was demonstrated with confocal laser immunofluorescence microscopy. Although tubulin bound to both $\mathrm{G} \alpha \mathrm{q}$ and $\mathrm{PLC} \beta_{1}, \mathrm{PIP}_{2}$ facilitated the interaction between tubulin and $P L C \beta_{1}$ but not that between tubulin and $G \alpha q$. However, $\mathrm{PIP}_{2}$ did augment formation of tubulin-G $\alpha \mathrm{q}-\mathrm{PLC} \beta_{1}$ complexes. Subsequent to potentiating PLC $\beta_{1}$ activation, sustained agonist-independent membrane binding of tubulin at $\mathrm{PIP}_{2}$ - and PLC $\beta_{1}$-rich sites appeared to inhibit $\mathrm{G} \alpha \mathrm{q}$ coupling to $\mathrm{PLC} \beta_{1}$. Furthermore, colchicine increased membraneassociated tubulin and also inhibited PLC $\beta_{1}$ activity in SK$\mathrm{N}-\mathrm{SH}$ cells. Thus, tubulin, depending on local membrane concentration, may serve as a positive or negative regulator of phosphoinositide hydrolysis. Rapid changes in membrane lipid composition or in the cytoskeleton might modify neuronal signaling through such a mechanism.

Key words: tubulin; phospholipid; microtubule; cytoskeleton; G-protein; phospholipase C; muscarinic receptor; acetylcholine; G-protein-coupled receptor; calcium; protein kinase C
The phosphatidylinositol 4,5-bisphosphate $\left(\mathrm{PIP}_{2}\right)$-specific phospholipase C (PLC) enzymes transduce signals by generating two second messengers, inositol 1,4,5-trisphosphate $\left(\mathrm{IP}_{3}\right)$ and diacylglycerol. The $\beta$ isoforms of these enzymes, $\operatorname{PLC} \beta_{1-3}$, are activated by the $\alpha$ subunit of the G-protein Gq (for review, see Rhee and Bae, 1997). Among the G-protein-coupled receptors linked to activation of $\mathrm{G} \alpha \mathrm{q}$ are the $\mathrm{m} 1, \mathrm{~m} 3$, and $\mathrm{m} 5$ muscarinic receptor subtypes.

The microtubule protein tubulin is involved in the control of G-protein-mediated signal transduction (Wang et al., 1990; Popova et al., 1994; Roychowdhury and Rasenick, 1994; Ravindra et al., 1996; Cote et al., 1997a,b). Association of tubulin with certain $\mathrm{G} \alpha$ subunits and the subsequent regulation of adenylyl cyclase and PLC $\beta_{1}$ signaling has been reported (Popova et al., 1994, 1997; Yan et al., 1996, 2001; Popova and Rasenick, 2000). After m1 muscarinic receptor stimulation in vitro (Popova et al., 1997) and in vivo (Popova and Rasenick, 2000), cytosolic tubulin translocates to the plasma membrane. Membrane-associated tubulin regulates PLC $\beta_{1}$ activation both in a positive and negative man-

\footnotetext{
Received Sept. 24, 2001; revised Nov. 29, 2001; accepted Nov. 29, 2001.

This study was supported by National Institutes of Health Grants MH 39595 and AG 15482 (M.M.R.) and Council for Tobacco Research Grant 4089 (M.M.R.). We thank Dr. S. G. Rhee for providing us with PLC $\beta_{1}$ baculovirus and PLC $\beta_{1}$ antibody and Dr. J. Garrison for the G $\alpha \mathrm{q}$ baculovirus. We also thank Drs. G. Luthin, D. Manning, W. Dunn, M. Gnegy, and E. Ross for the generous gifts of material.

Correspondence should be addressed to Mark M. Rasenick, Department of Physiology and Biophysics, University of Illinois at Chicago, College of Medicine, 835 South Wolcott Avenue, m/c 901, Chicago, IL 60612-7342. E-mail raz@uic.edu. Copyright (C) 2002 Society for Neuroscience 0270-6474/02/221668-11\$15.00/0
}

ner (Popova et al., 1997). At low (nanomolar) concentrations, tubulin activates PLC $\beta_{1}$, whereas at higher concentrations, enzyme inhibition is observed.

Previous studies have indicated that transactivation of $\mathrm{G} \alpha \mathrm{q}$, through a direct GTP transfer from tubulin, is responsible for PLC $\beta_{1}$ activation by tubulin (Popova et al., 1997; Popova and Rasenick, 2000). However, the mechanism behind the inhibition of PLC $\beta_{1}$, observed at high dimeric tubulin concentrations, has not been elucidated.

Tubulin binds $\mathrm{PIP}_{2}$, and this inhibits microtubule polymerization (Popova et al., 1997). Because PIP P $_{2}$ is the PLC preferred substrate, sequestration of $\mathrm{PIP}_{2}$ by tubulin should also affect important phosphoinositide-dependent signaling pathways. By analogy, several actin-binding proteins, such as profilin, gelsolin, and $\mathrm{CapG}$, have already been shown to bind $\mathrm{PIP}_{2}$ and to modulate the activity of regulatory PLC isozymes both in vitro (Goldschmidt-Clermont et al., 1990, 1991; Banno et al., 1992; Steed et al., 1996; Sun et al., 1997) and in vivo (Sun et al., 1997). The binding of $\mathrm{PIP}_{2}$ by the above-mentioned proteins appears to prevent phospholipase access to this substrate (GoldschmidtClermont et al., 1990, 1991; Banno et al., 1992; Steed et al., 1996; Sun et al., 1997). Because high tubulin concentrations inhibit PLC $\beta_{1}$ in vitro, a similar inhibitory mechanism was suggested (Popova et al., 1997).

This study was designed to evaluate the interaction between tubulin and $\mathrm{PIP}_{2}$ and test how this interaction affects $\mathrm{G} \alpha \mathrm{q}$ and PLC $\beta_{1}$ activation at the membrane. The results reveal that PIP binding to tubulin is specific but does not affect the binding and 
hydrolysis of GTP by tubulin. Although activated muscarinic receptors recruit tubulin from the cytosol to the membrane, leading to $\mathrm{G} \alpha \mathrm{q}$ transactivation, receptor-independent binding of tubulin to $\mathrm{PIP}_{2}$-rich sites on the membrane obstructs PLC $\beta_{1}$ activation. Thus, it appears that tubulin and $\mathrm{PIP}_{2}$ interact to effect a dual regulation of PLC $\beta_{1}$. Such a mechanism might prove important in regulating the response and responsiveness of G-protein-mediated phospholipid signaling in neuronal and glial cells.

\section{MATERIALS AND METHODS}

Baculovirus-directed expression of signaling proteins in Sf9 cells. Sf9 cells were maintained in Sf-900 II SFM media (Invitrogen, Carlsbad, CA) as described previously (Popova et al., 1997). They were infected with baculoviruses bearing the $\mathrm{m} 1$ muscarinic receptor, $\mathrm{G} \alpha \mathrm{q}$, or PLC $\beta_{1}$ cDNAs, as was done previously (Popova et al., 1997). The construction of recombinant baculoviruses was already reported previously (Parker et al., 1991; Graber et al., 1992; Boguslavsky et al., 1994). Cells were harvested after $65 \mathrm{hr}$, and membranes were prepared and frozen in liquid nitrogen for subsequent use as described previously (Popova et al., 1994, 1997). Protein concentrations were determined by Coomassie blue binding (Bradford, 1976). Bovine serum albumin was used as a standard. Protein expression was measured by immunoblotting. Antisera specific for the $\mathrm{m} 1$ muscarinic receptor (number 71; from G. Luthin, MCP Hahnemann University, Philadelphia, PA), G $\alpha \mathrm{q} / 11$ (number 0945; from D. Manning, University of Pennsylvania, Philadelphia, PA), and PLC $\beta_{1}$ (antiholoenzyme; from S. G. Rhee, National Institutes of Health, Bethesda, MD) were used at a dilution of 1:500. Biotinylated goat anti-rabbit IgG or anti-mouse $\operatorname{IgG}$ and streptavidin-alkaline phosphatase conjugate were used for detection. Densitometry was performed to evaluate the expression levels (Storm 840; Molecular Dynamics, Sunnyvale, CA; Popova et al., 1997; Popova and Rasenick, 2000). m1 muscarinic receptor density was determined by $\left[{ }^{3} \mathrm{H}\right] \mathrm{L}-$ quinuclidinyl [phenyl4(n)]benzilate $\left(\left[{ }^{3} \mathrm{H}\right] \mathrm{QNB}\right)$ binding (Popova et al., 1997).

Tubulin preparations. Microtubule proteins were isolated (Shelanski et al., 1973), and tubulin preparations purified free of microtubuleassociated proteins by phosphocellulose chromatography were prepared as described previously (Wang and Rasenick, 1991). Phosphocellulosepurified tubulin (PC-tubulin) was $>95 \%$ pure as determined on SDS-PAGE.

$\mathrm{P}^{3}$ (4-azidoanilido)-P1-5'-GTP (AAGTP) and [ $\left.{ }^{32} \mathrm{P}\right]$ AAGTP were synthesized as described previously (Rasenick et al., 1994). Tubulin$\left[{ }^{32} \mathrm{P}\right] \mathrm{AAGTP}$ was made from PC-tubulin as indicated (Rasenick and Wang, 1988). The final preparations contained $0.4-0.6 \mathrm{~mol}$ of nucleotide bound $/ \mathrm{mol}$ of tubulin. Tubulin-[ $\left.{ }^{32} \mathrm{P}\right] \mathrm{AAGTP}$ concentrations used throughout the study were based on the protein concentration.

To prepare tubulin labeled covalently with fluorescein-5-maleimide (FM-tubulin), FM (Molecular Probes, Eugene, OR) was incubated with $\mathrm{PC}$-tubulin at a $5: 1$ molar ratio at $37^{\circ} \mathrm{C}$ for $30 \mathrm{~min}$ in polymerization buffer [100 mM 1,4-piperazinediethanesulfonic acid (Pipes), $2 \mathrm{~mm}$ EGTA, $4 \mathrm{~mm} \mathrm{MgCl}_{2}, 1 \mathrm{~mm}$ GTP, pH 6.9, and $1 \mathrm{M}$ glutamate]. The reaction was quenched with $1 \mathrm{~mm} \beta$-mercaptoethanol, and the samples were layered onto warm $40 \%$ sucrose containing $1 \mathrm{~mm}$ GTP and centrifuged at $200,000 \times g$ at $37^{\circ} \mathrm{C}$ for $30 \mathrm{~min}$. The FM-tubulin pellet was washed twice with warm buffer and depolymerized on ice, followed by chromatography through a P6-DG column (Bio-Rad, Hercules, CA) twice to remove free FM. The calculated ratio of FM labeling of tubulin was 1:1. FM-tubulin was polymerization-competent as tested by electron microscopy performed as described previously (Popova et al., 1997).

Microtubule assembly. To test the effects of various phospholipids on microtubule assembly, phosphocellulose-purified tubulin $(1.5 \mathrm{mg} / \mathrm{ml})$ was incubated in a bath sonicator for $15 \mathrm{~min}$ at $4^{\circ} \mathrm{C}$ with different phosphoinositides, $\mathrm{IP}_{3}$, or heparin (as indicated), at a molar ratio of 1:6 in polymerization buffer (in mM: 100 Pipes, 2 EGTA, $3 \mathrm{MgCl}_{2}$, and $1 \mathrm{GTP}$, $\mathrm{pH}$ 6.9). The assembly reaction was performed for $1 \mathrm{hr}$ at $37^{\circ} \mathrm{C}$ in a shaking water bath. The polymer mass was isolated by centrifugation at $150,000 \times g$ for $30 \mathrm{~min}$ at $37^{\circ} \mathrm{C}$, followed by separation of the pellets and the supernatants. Pellets were resuspended in identical amounts of cold polymerization buffer on ice, and protein concentrations were measured by the method of Bradford (1976) using BSA as a standard. The amount of protein in the pelleted polymer mass without any additions (control) was $0.47 \pm 0.10 \mathrm{mg} / \mathrm{ml}$. The depolymerized pellets were subjected to SDS-PAGE and immunoblotting with a monoclonal anti- $\alpha$-tubulin anti- body (Santa Cruz Biotechnology, Santa Cruz, CA) and ECL detection (Amersham Biosciences, Piscataway, NJ). The results were analyzed in a Storm 840 imaging system (Molecular Dynamics). Samples from microtubule polymerization reactions were also examined by electron microscopy (Popova et al., 1997) to evaluate the effect of lipids on microtubule assembly.

To study whether the effect of $\mathrm{PIP}_{2}$ on microtubule assembly was concentration-dependent, polymerization of phosphocellulose-purified tubulin $(2.5 \mathrm{mg} / \mathrm{ml})$ was monitored by turbidity measurement at $350 \mathrm{~nm}$ in a Beckman DU 640B spectrophotometer at $37^{\circ} \mathrm{C}$. PIP 2 , phosphatidylcholine (PC), or vesicles of PIP $P_{2}$ and PC (at a molar ratio of 1:1) were mixed with tubulin (tubulin/lipid molar ratio of 1:6) in polymerization buffer on ice to a final volume of $300 \mu \mathrm{l}$. Samples were transferred to a quartz cuvette, and the increase in absorbance was monitored at $37^{\circ} \mathrm{C}$.

GTPase activity of tubulin. To determine the amount or the species of the guanine nucleotide bound to tubulin and the extent of GTP hydrolysis, phosphocellulose-purified tubulin was made nucleotide-free by incubation with charcoal (Rasenick and Wang, 1988). This tubulin was then incubated with $0.2 \mathrm{mM}\left[{ }^{32} \mathrm{P}\right] \mathrm{GTP}$ for $30 \mathrm{~min}$ on ice. After two passes through Bio-Gel P6-DG columns to remove unbound nucleotide, tubulin GTPase activity was determined. Tubulin $-\left[{ }^{32} \mathrm{P}\right] \mathrm{GTP}$ was incubated for $30 \mathrm{~min}$ at $30^{\circ} \mathrm{C}$, followed by nucleotide analysis by thin-layer chromatography (TLC) on polyethyleneimide cellulose as described previously (Roychowdhury and Rasenick, 1994). The chromatograms were developed in $0.35 \mathrm{M} \mathrm{NH}_{4} \mathrm{HCO}_{3}$. The spots containing GTP or GDP standards were visualized with a UV lamp, and the plate was exposed to film for autoradiography or subjected directly to phosphorimage analysis (Storm 840; Molecular Dynamics). When indicated, phosphoinositides (at a molar ratio of $6: 1)$ were added to tubulin- $\left[{ }^{32} \mathrm{P}\right] \mathrm{GTP}$ before incubation (Popova et al., 1997).

Analysis of nucleotide bound to tubulin. Phosphocellulose-purified tubulin was loaded with $\left[{ }^{32} \mathrm{P}\right] \mathrm{AAGTP}$ or $\left[{ }^{32} \mathrm{P}\right] \mathrm{GTP}$, as described above, in the presence or absence of phosphoinositides (tubulin/phosphoinositide ratio of 1:6). [ $\left.{ }^{32} \mathrm{P}\right]$ AAGTP-labeled samples were subjected to TLC, followed by autoradiography or phosphorimage analysis, as indicated. Tubulin samples labeled by $\left[{ }^{32} \mathrm{P}\right]$ GTP were subjected to P6-DG column chromatography, and the radioactivity of $5 \mu$ l of each tubulin $-\left[{ }^{32} \mathrm{P}\right] \mathrm{GTP}$ eluate was measured by liquid scintillation counting.

To test whether PIP $\mathrm{P}_{2}$ caused dissociation of the guanine nucleotide bound to tubulin, $\mathrm{PIP}_{2}$ was added at the end of the binding reaction. The samples were kept on ice for an additional $30 \mathrm{~min}$ before being processed as described above.

Phosphoinositide preparation. Phosphoinositides were evaporated under a stream of nitrogen, sonicated for $5 \mathrm{~min}$ (at appropriate concentrations) in assay buffer on ice, and used immediately.

Photoaffinity labeling. Membranes from Sf9 or SK-N-SH cells were incubated with the indicated concentrations of tubulin- $\left[{ }^{32} \mathrm{P}\right]$ AAGTP, $\mathrm{PIP}_{2}$, and carbachol as described previously (Popova et al., 1994, 1997). After UV irradiation and centrifugation, membrane pellets were dissolved in Laemmli buffer and subjected to SDS-PAGE as done previously (Popova et al., 1994, 1997). Gels were either stained (Coomassie blue) or subjected to Western blotting, followed by autoradiography (XAR-5 film; Eastman Kodak Co., Rochester, NY) or phosphorimaging. Densitometric measurements of autoradiograms and phosphorimage analysis of the gels were performed, respectively (Storm 840; Molecular Dynamics). Tubulin-[ $\left.{ }^{32} \mathrm{P}\right]$ AAGTP and Sf9 membranes, overexpressing G $\alpha \mathrm{q}$, were run along the samples to identify the bands of tubulin and Goq. As shown previously (Popova and Rasenick, 2000), carbachol-evoked membrane association of tubulin and $\mathrm{G} \alpha \mathrm{q}$ transactivation by tubulin were consistently reversed by atropine.

Immunoprecipitation. Sf9 cells were infected separately or simultaneously (according to the experimental design) with baculoviruses bearing the $\mathrm{m} 1$ muscarinic receptor, G $\alpha \mathrm{q}$, or PLC $\beta_{1}$ cDNA as described previously (Popova et al., 1997). Membrane preparations were extracted with $1 \%$ sodium cholate for $1 \mathrm{hr}$ at $4^{\circ} \mathrm{C}$ and constant stirring (Popova et al., 1997). After centrifugation at $20,000 \pm g$ at $4^{\circ} \mathrm{C}$ the extracts $(0.5$ $\mathrm{mg} / \mathrm{ml}$ membrane protein) were incubated with $1 \mu \mathrm{M}$ of tubulin$\left[{ }^{32} \mathrm{P}\right]$ AAGTP as described previously (Popova et al., 1997). When tested, PIP $_{2}$ was preincubated with tubulin- $\left[{ }^{32} \mathrm{P}\right] \mathrm{AAGTP}$ at a molar ratio of $6: 1$ for $15 \mathrm{~min}$ in a Branson (Danbury, CT) water bath sonicator at $4^{\circ} \mathrm{C}$. After UV irradiation and preclearing with Pansorbin (Calbiochem, La Jolla, CA), each sample was incubated overnight with appropriate antiserum or preimmune serum $\left(1: 20\right.$ dilution) at $4^{\circ} \mathrm{C}$ with constant shaking. Immune complexes were precipitated with Pansorbin and subjected to SDS-PAGE 
and autoradiography or phosphorimage analysis. The antisera used showed no cross-reactivity to tubulin.

Analysis of phosphoinositide hydrolysis in SK-N-SH cells. SK-N-SH neuroblastoma cells were grown in six-well plates in DMEM supplemented with $10 \%$ fetal bovine serum and $50 \mathrm{U} / \mathrm{ml}$ penicillinstreptomycin. Twenty-four hours before the experiment, inositol-free DMEM supplemented with $2 \mu \mathrm{Ci} /$ well myo- $\left[{ }^{3} \mathrm{H}\right]$ inositol was added. The cells were washed three times with Locke's buffer, containing $10 \mathrm{~mm}$ $\mathrm{LiCl}$, and incubated for $15 \mathrm{~min}$ with or without $33 \mu \mathrm{M}$ colchicine in the same buffer. After triplicate wash with Locke's buffer, $10 \mu \mathrm{M}$ carbachol was added as indicated, and the cells were incubated for $30 \mathrm{~min}$ at $37^{\circ} \mathrm{C}$. Carbachol effects were routinely controlled for by addition of $1 \mu \mathrm{M}$ atropine. The reaction was stopped with ice-cold $10 \%$ trichloroacetic acid, and the cells were scraped from wells with a rubber policeman and transferred to tubes. After sonication (as described above) and centrifugation at $20,000 \times g$ for $15 \mathrm{~min}\left(4^{\circ} \mathrm{C}\right)$, the supernatants were extracted with water-saturated ether and neutralized with $1 \mathrm{M} \mathrm{NH}_{4} \mathrm{HCO}_{3}$. Ion exchange chromatography (Dowex AG 1-X8 resin, formate form; Bio$\mathrm{Rad}$ ) of the samples was performed as described previously (Popova and Dubocovich, 1995). Total $\left[{ }^{3} \mathrm{H}\right]$ inositol phosphates were quantified by liquid scintillation counting. The inositol phosphate content of SK-N-SH cells at the start of the experiment $\left(0 \%\right.$ increase) was $1.1 \pm 0.27 \times 10^{3}$ $\mathrm{dpm} / 10^{6}$ cells.

Recording of enhanced green fluorescent protein-tubulin-containing SK$\mathrm{N}$-SH cells by immunofluorescence microscopy. Cells plated on 35-mmdiameter Delta $\mathrm{T}$ dishes (Biotechs, Inc.) were transiently transfected with $5 \mu \mathrm{g}$ enhanced green fluorescent protein (EGFP)-tubulin cDNA (Clontech, Cambridge, UK) using Lipofectin reagent as described by the manufacturer (Invitrogen, Gaithersburg, MD). The cells were observed $24 \mathrm{hr}$ later using fluorescence microscopy. A Nikon fluorescence microscope equipped with a $100 \mathrm{~W}$ mercury arc lamp was used. Before observation, the medium in the dish was changed to serum-free DMEM containing $20 \mathrm{~mm}$ HEPES, and the cells were maintained in this media for at least $30 \mathrm{~min}$ before the recording. The cells were transferred to the microscope stage and maintained at $37^{\circ} \mathrm{C}$ during the entire period of observation. Images were acquired with an interline charge-coupled device camera (1300 YHS; Roper Scientific, Trenton, NJ) driven by IP Lab imaging software (Scananlatics, Inc., Suitland, VA). Fluorescent images for EGFP were recorded every $15 \mathrm{sec}$ and the recorded images were processed with IP Lab.

Confocal immunofluorescence microscopy. SK-N-SH neuroblastoma cells were plated onto glass coverslips in 12-well culture plates at a density of $1 \times 10^{5}$. After $24 \mathrm{hr}$, cells were incubated for $15 \mathrm{~min}$ with or without $33 \mu \mathrm{M}$ colchicine. After a PBS wash, the cells were treated for 2 min with $1 \mathrm{mM}$ carbachol, $10 \mu \mathrm{M}$ atropine, or both. The cells were immediately fixed in $-20^{\circ} \mathrm{C}$ methanol for $3 \mathrm{~min}$ and washed three times, $10 \mathrm{~min}$ each, in PBS containing $0.1 \%$ Triton X-100. The cells were blocked for $40 \mathrm{~min}$ in PBS containing $5 \%$ milk and washed in PBS. Subsequently the cells were incubated for $1 \mathrm{hr}$ with a polyclonal antitubulin antibody (raised against the C-terminal 422-431 amino acid region of $\beta$-tubulin; Popova and Rasenick, 2000) and a monoclonal anti-PIP ${ }_{2}$ antibody (Assay Designs, Inc.), both at a dilution of 1:100. After a PBS wash, secondary fluorescein isothiocyanate (FITC)conjugated goat anti-rabbit and Texas Red-conjugated horse anti-mouse antibodies (Vector Laboratories, Burlingame, CA; 1:100 dilution) were applied for $1 \mathrm{hr}$, followed by washing and mounting of the coverslips. Images were acquired using a Zeiss (Thornwood, NY) LSM 510 laser scanning confocal microscope equipped with a $63 \times$ water immersion objective. A $488 \mathrm{~nm}$ beam from an argon-krypton laser was used for the excitation of FITC, whereas a $543 \mathrm{~nm}$ beam was used for Texas Red excitation. Emission from FITC was detected through a BP505 filter, whereas emission from Texas Red was detected through an LP560 filter. Areas of antibody colocalization appeared in yellow. Differential interference contrast images of the cells were regularly acquired as well. Coverslips were examined at random. For each experimental condition, a total of 90 randomly selected cells over three consecutive experiments were evaluated for tubulin and $\mathrm{PIP}_{2}$ distribution and colocalization. Final image composites were created using Adobe Photoshop 5.0. No specific FITC or Texas Red labeling was observed in cells treated with rabbit or mouse preimmune serum instead of anti- $\beta$-tubulin or anti-PIP 2 antibodies, respectively. FITC labeling was not observed when the antitubulin antiserum was preincubated overnight at $4^{\circ} \mathrm{C}$ with $\mathrm{PC}$-tubulin (1:1 ratio), and Texas Red labeling was not detected when the anti-PIP 2 antiserum was preincubated with $\mathrm{PIP}_{2}$ (1:1 ratio), both conditions tested at the same antibody dilutions (1:100) afterward. Although colchicine treatment changed the shape of the treated cells, it did not affect the membrane localization and intracellular distribution of $\mathrm{G} \alpha \mathrm{q}$ (Ibarrondo et al., 1995).

Materials. $\left[\alpha^{32} \mathrm{P}\right]$ GTP was from ICN Biomedicals (Cleveland, $\mathrm{OH}$ ). $\left[{ }^{3} \mathrm{H}\right] \mathrm{QNB}$ was from Amersham Biosciences. Carbachol and all phosphoinositides used were from Sigma (St. Louis, MO). Fluorescein-5maleimide was from Molecular Probes. $p$-Azidoaniline was synthesized by Dr. William Dunn III (University of Illinois at Chicago). All other reagents were of analytical grade.

\section{RESULTS}

\section{Specific interaction with $\mathrm{PIP}_{2}$ decreases tubulin polymerization}

Previous experiments demonstrated that $\mathrm{PIP}_{2}$ bound to tubulin and inhibited microtubule assembly (Popova et al., 1997). The specificity of tubulin-PIP $\mathrm{P}_{2}$ interaction was not addressed in that study. Phosphatidylinositol 3,4,5-trisphosphate $\left(\mathrm{PIP}_{3}\right)$ as well as the second messenger $\mathrm{IP}_{3}$ can bind to certain $\mathrm{PIP}_{2}$-binding protein domains (Ferguson et al., 1995; Kavran et al., 1998), and the negative charge of these molecules was presumed responsible for such interaction. The anionic phospholipid constituents of hepatic membranes have also been reported to account for membrane binding of brain microtubule protein and inhibition of assembly (Reaven and Azhar, 1981). A hydrophobic interaction of tubulin (Andreu, 1986) with the uncharged phospholipid phosphatidylcholine at the lipid phase transition temperature (Klausner et al., 1981; Kumar et al., 1981) has been found as well.

To investigate the specificity of tubulin interaction with the anionic phospholipid $\mathrm{PIP}_{2}$, several charged and neutral phospholipids as well as $\mathrm{IP}_{3}$ were included in microtubule polymerization assays. PC-tubulin, purified free of microtubule-associated proteins, was preincubated with the phospholipids tested or $\mathrm{IP}_{3}$. These tubulin preparations were allowed to polymerize under conditions that favor microtubule assembly (see Materials and Methods). In each case, the amount of tubulin distributed between the pelleted polymer mass and the supernatant was measured. The results obtained demonstrated that $\mathrm{PIP}_{2}$ inhibited tubulin polymerization by $39.9 \pm 3.6 \%(\mathrm{SEM} ; n=5)$ compared with the control not containing this phosphoinositide (Fig. 1A). Other closely related anionic phosphoinositides, such as $\mathrm{PIP}_{3}$, phosphatidylinositol 3-phosphate (PIP), and phosphatidylinositol (PI), as well as the negatively charged inositol phosphate $\mathrm{IP}_{3}$, had no significant effect on the microtubule assembly process. When tested under the same conditions, the polyanion heparin also had no effect on tubulin assembly. The neutral phospholipids PC and phosphatidylethanolamine (PE) did not significantly affect polymerization either (Fig. 1A). Electron microscopy and light scattering of tubulin samples was also done. As was the case with microtubule pellets, $\mathrm{PIP}_{2}$ but not $\mathrm{PIP}_{3}, \mathrm{PC}, \mathrm{PE}, \mathrm{PI}$, or $\mathrm{IP}_{3}$ inhibited microtubule formation. Thus, it is suggested that the regulatory phosphoinositide $\mathrm{PIP}_{2}$ inhibits microtubule polymerization through a specific interaction with tubulin.

To test whether the effect of $\mathrm{PIP}_{2}$ on tubulin was concentration-dependent, tubulin polymerization was studied in the absence or presence of $\mathrm{PIP}_{2}, \mathrm{PC}$, or the mixture of both in light-scattering experiments (Fig. $1 B$ ). When the concentration of $\mathrm{PIP}_{2}$ was reduced by half $\left(\mathrm{PIP}_{2}\right.$ mixed with $\mathrm{PC}$ at a molar ratio of $1: 1)$, the inhibition of microtubule formation was also half that seen with $\mathrm{PIP}_{2}$ alone.

\section{PIP $_{2}$ does not affect the binding and hydrolysis of GTP by tubulin}

Several possible mechanisms exist through which PIP $_{2}$ binding could interfere with tubulin polymerization. One possibility is 
$\mathbf{A}$
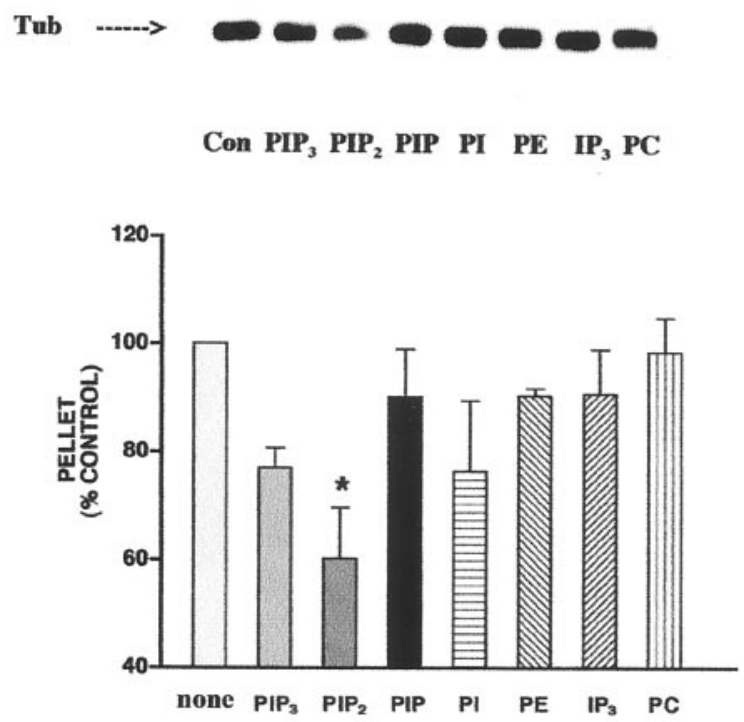

Additions to tubulin polymerization assay

B

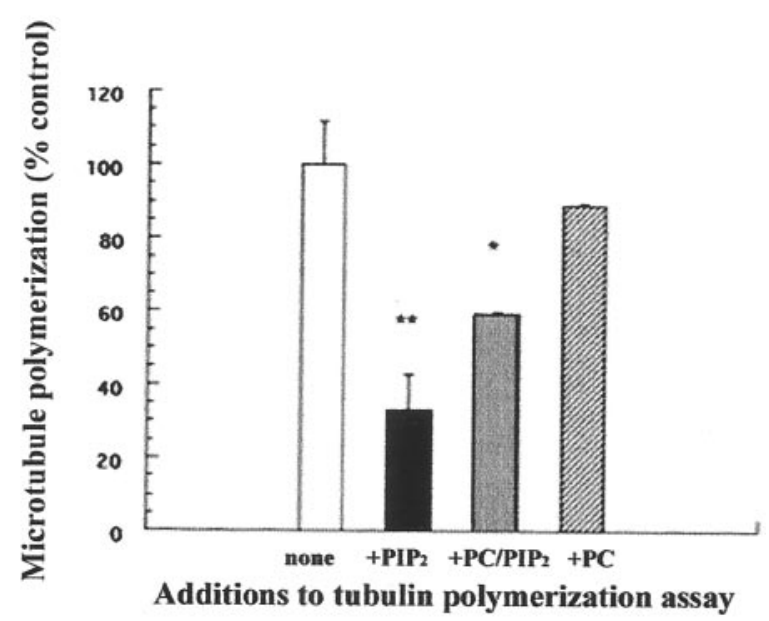

Figure 1. $\mathrm{PIP}_{2}$ inhibits tubulin polymerization. $A$, Comparison of the effects of various phosphoinositides on microtubule polymerization. Where indicated, $\mathrm{PIP}_{3}, \mathrm{PIP}_{2}$, PIP, PI, PC, PE, and the inositol phosphate $\mathrm{IP}_{3}$ (final molar concentration of $75 \mu \mathrm{M}$ ) were preincubated with tubulin $(T u b)$ as described in Materials and Methods. Microtubule polymerization reactions were performed for $1 \mathrm{hr}$ at $37^{\circ} \mathrm{C}$. Pellets were resuspended in cold polymerization buffer and subjected to SDS-PAGE and immunoblotting with a monoclonal anti- $\alpha$ tubulin antibody. Values are means \pm SEM of five independent experiments performed in triplicate. *Significantly different from the control (tubulin, subjected to polymerization without any addition); $p<0.05$, one-way ANOVA. Colorimetric measurements of the protein content of depolymerized pellets (performed before SDS-PAGE) corroborated these findings. $B, \mathrm{PIP}_{2}$ inhibition of microtubule formation is concentration-dependent. $\mathrm{PIP}_{2}, \mathrm{PC}$, mixed vesicles of $\mathrm{PIP}_{2}$ and PC (at the ratio of 1:1), and vehicle were added to microtubule polymerization reactions. Polymerization was performed for $30 \mathrm{~min}$ as described in Materials and Methods. Absorbance at $350 \mathrm{~nm}$ was monitored. Values were obtained after $20 \mathrm{~min}$, when the polymerization reactions were at equilibrium. Values are means \pm SEM of three separate experiments done in triplicate. The net absorbance of microtubule polymerization reactions without added phosphoinositides was $1.09 \pm 0.12$ (control). ${ }^{*} p<0.05 ;{ }^{* *} p<0.01$.
$\mathbf{A}$

$\mathbf{B}$
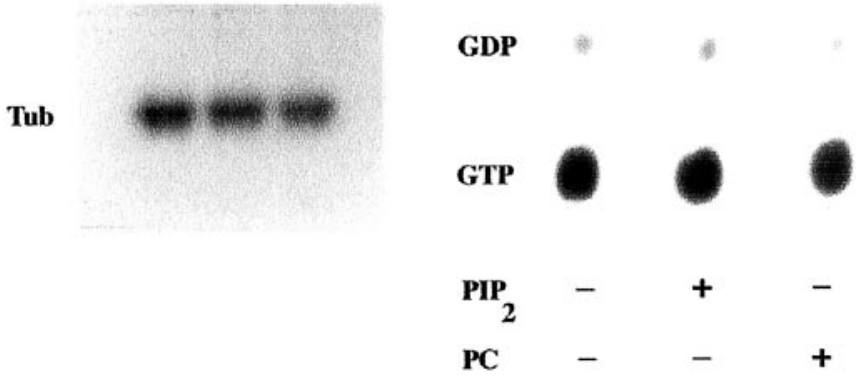

Figure 2. $\mathrm{PIP}_{2}$ does not alter binding and hydrolysis of GTP by tubulin. $A$, Effects of $\mathrm{PIP}_{2}$ on $\left[{ }^{32} \mathrm{P}\right] \mathrm{AAGTP}$ binding to tubulin $(\mathrm{Tub})$. Phosphocellulose-purified tubulin, stripped of nucleotide, was incubated with $\left[{ }^{32} \mathrm{P}\right] \mathrm{AAGTP}$ in the absence or presence of phosphoinositides. First lane, No addition to the binding reaction; second lane, $\mathrm{PIP}_{2}$ added at the start of the binding reaction; third lane, $\mathrm{PIP}_{2}$ added after the end of the binding reaction, as described. A representative of two identical experiments performed in triplicate with similar results is shown. $B$, Effects of $\mathrm{PIP}_{2}$ on GTPase activity of tubulin. Tubulin $-\left[{ }^{32} \mathrm{P}\right] \mathrm{GTP}$ was incubated for $30 \mathrm{~min}$ at $30^{\circ} \mathrm{C}$, in the absence or presence of phosphoinositides, and the nucleotide bound to tubulin was analyzed as described in Materials and Methods. A representative of two identical experiments performed in triplicate with similar results is shown.

that PIP $\mathrm{P}_{2}$ affects the binding of GTP to tubulin, because $\mathrm{PIP}_{2}$ has been reported to promote dissociation of GTP from the small GTP-binding proteins Arf, CDC 42, and Rho (Terui et al., 1994; Glaven et al., 1996). Another scenario is that GTP hydrolysis on tubulin is activated by PIP $_{2}$. Because tubulin must bind GTP to assemble, $\mathrm{PIP}_{2}$ could block the process by activating tubulin GTPase.

$\mathrm{PIP}_{2}$ did not modify the amount of $\left[{ }^{32} \mathrm{P}\right] \mathrm{AAGTP}$ or $\left[{ }^{32} \mathrm{P}\right] \mathrm{GTP}$ bound to tubulin, estimated at $0.49 \pm 0.08 \mathrm{~mol}$ bound $/ \mathrm{mol}$ of tubulin (Fig. 2A). This was independent of whether $\mathrm{PIP}_{2}$ was added to tubulin before or after the course of the guanine nucleotide binding reaction. Densitometry revealed relative absorbance values of $100.0 \pm 14.6$ for the tubulin- $\left[{ }^{32} \mathrm{P}\right]$ AAGTP band obtained when $\mathrm{PIP}_{2}$ was not present in the binding reaction, as well as $94.41 \pm 10.2$ and $103.3 \pm 15.1$ for the bands obtained when $\mathrm{PIP}_{2}$ was added before or after the binding reaction, respectively ( $p>0.05 ; n=6$ for each experimental condition).

Tubulin contains an intrinsic GTPase, which is not activated until the microtubule is formed (Carlier and Pantaloni, 1981). If $\mathrm{PIP}_{2}$ activated the GTPase of tubulin dimers, polymerization would be blocked, because those dimers would be binding GDP. However, PIP $P_{2}$ did not promote hydrolysis of GTP by tubulin. The amount of GTP bound per mole of tubulin remained at $0.55 \pm 0.05 \mathrm{~mol} / \mathrm{mol}$ during the course of these experiments regardless of the presence or absence of phospholipids $(p>0.05$; $n=6$ for each experimental condition; Fig. $2 B$ ).

\section{$\mathrm{PIP}_{2}$ promotes association of tubulin with the membrane but does not promote Gaq transactivation by tubulin}

$\mathrm{PIP}_{2}$ is normally membrane-associated. Although it is not clear how tubulin associates with membranes (a subject of some controversy), it is possible that $\mathrm{PIP}_{2}$ is involved in the process (Reaven and Azhar, 1981). This was investigated using both membranes prepared from Sf9 cells expressing recombinant $\mathrm{m} 1$ muscarinic receptors, G $\alpha \mathrm{q}$, and PLC $\beta_{1}$ (Popova et al., 1997) and membranes from SK-N-SH neuroblastoma cells, which normally 
A

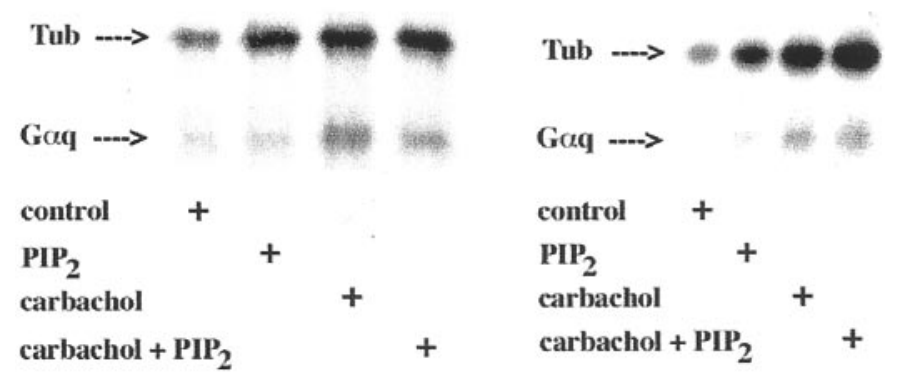

Figure 3. $\mathrm{PIP}_{2}$ binding increases membrane-associated tubulin (Tub). A, Membranes from Sf9 cells expressing $\mathrm{m} 1$ muscarinic receptors, G $\alpha \mathrm{q}$, and PLC $\beta_{1}(20 \mu \mathrm{g}$ of membrane protein) were incubated with $300 \mathrm{~nm}$ tubulin[ $\left.{ }^{32} \mathrm{P}\right]$ AAGTP with or without $100 \mu \mathrm{M}$ carbachol, $30 \mu \mathrm{M} \mathrm{PIP}$, or both for $5 \mathrm{~min}$ at $23^{\circ} \mathrm{C}$, followed by UV irradiation, SDS-PAGE (50 $\mu \mathrm{g}$ of membrane protein in each lane), and autoradiography. A representative of three similar experiments performed in triplicate is shown. $B$, Membranes from SK-N-SH cells (40 $\mu \mathrm{g}$ of membrane protein) were incubated with tubulin- $\left[{ }^{32} \mathrm{P}\right]$ AAGTP or carbachol, $\mathrm{PIP}_{2}$, or both under the conditions described above. A representative of two identical experiments performed in triplicate with similar results is shown.

contain m3 muscarinic receptors, G $\alpha \mathrm{q}$, and PLC $\beta_{1}$ (Fisher and Heacock, 1988).

In membranes from infected Sf9 or SK-N-SH cells, both carbachol and $\mathrm{PIP}_{2}$ increased the association of tubulin with the membrane (Fig. 3). At the experimental conditions used (Fig. $3 A)$, the average increase in association of tubulin $-\left[{ }^{32} \mathrm{P}\right]$ AAGTP with the Sf9 cell membranes was $99.6 \pm 22.4 \%(\mathrm{SD} ; n=3)$ in the presence of carbachol and $96.1 \pm 17.7 \%(n=3)$ in the presence of $\mathrm{PIP}_{2}$. When both of them were present, association of tubulin with the membrane was $115.1 \% \pm 29.2 \%(n=3)$ greater than that of the control. Comparable results were obtained when membranes from SK-N-SH cells were tested (Fig, 3B).

$\mathrm{G} \alpha \mathrm{q}$ activation by tubulin was also assessed in these experiments by examining the transfer of $\left[{ }^{32} \mathrm{P}\right]$ AAGTP from tubulin to $\mathrm{G} \alpha \mathrm{q}$. Although $\mathrm{G} \alpha \mathrm{q}$ transactivation by tubulin increased by $124.0 \pm 23.0 \%(\mathrm{SD} ; n=3)$ after muscarinic receptor stimulation (Fig. $3 A$ ), it was not affected by $\mathrm{PIP}_{2}$. Atropine inhibited the membrane association of tubulin evoked by carbachol, but it failed to suppress the $\mathrm{PIP}_{2}$-promoted membrane association of tubulin. These findings were corroborated when SK-N-SH membranes were tested under similar experimental conditions (Fig. 3B).

Concentration-response experiments were performed to inspect the effect of $\mathrm{PIP}_{2}$ on tubulin regulation of $\mathrm{G} \alpha \mathrm{q} . \mathrm{PIP}_{2}$ increased the binding of exogenous tubulin to Sf9 membranes containing the recombinant proteins over a range of tubulin concentrations. Both FM-tubulin (Fig. 4A) and tubulin$\left[{ }^{32} \mathrm{P}\right]$ AAGTP gave similar results. The effects of PIP $\mathrm{P}_{2}$ on tubulin$\left[{ }^{32} \mathrm{P}\right]$ AAGTP membrane association were also concentrationdependent (Fig. 4B). However, as shown in Figure $4 C$, over a range of tubulin $-\left[{ }^{32} \mathrm{P}\right]$ AAGTP concentrations, transactivation of $\mathrm{G} \alpha \mathrm{q}$ by tubulin was independent of $\mathrm{PIP}_{2}$. In fact, a decrease in the carbachol-evoked [ ${ }^{32} \mathrm{P}$ ]AAGTP transfer from tubulin to G $\alpha \mathrm{q}$ was observed at $\mathrm{PIP}_{2}$ concentrations of $>40 \mu \mathrm{M}$ (Fig. 4D). Thus, although $\mathrm{PIP}_{2}$ promoted tubulin association with the membrane, it did not evoke the rapid process of $\mathrm{G} \alpha \mathrm{q}$ transactivation by tubulin. These results are consistent with the notion that $\mathrm{PIP}_{2}$ binding to tubulin interfered with both tubulin polymerization properties and the ability to transactivate $\mathrm{G} \alpha \mathrm{q}$.
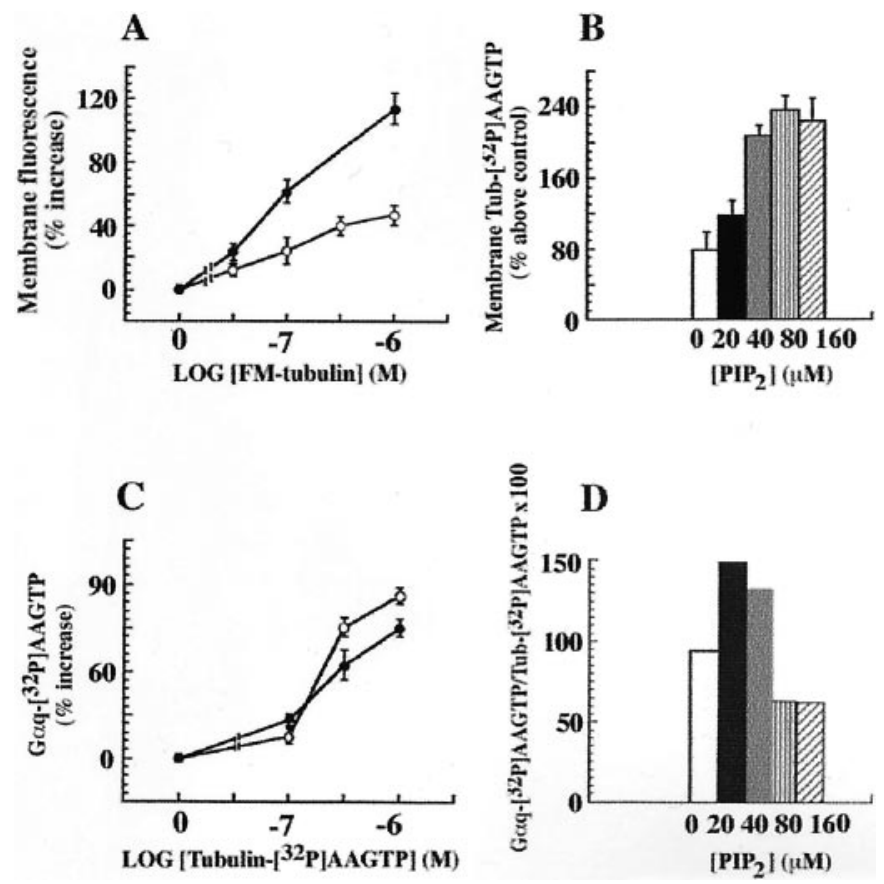

Figure 4. $\mathrm{PIP}_{2}$ does not increase $\mathrm{G} \alpha \mathrm{q}$ transactivation by tubulin. $A$, The effects of carbachol and $\mathrm{PIP}_{2}$ on the membrane association of tubulin are additive. Recruitment of tubulin to the membrane was studied using increasing concentrations of FM-tubulin. Membranes from Sf9 cells expressing $\mathrm{m} 1$ muscarinic receptors, G $\alpha \mathrm{q}$, and PLC $\beta_{1}$ were incubated with carbachol and FM-tubulin (at the indicated concentrations), with or without PIP $_{2}$. SDS-PAGE (50 $\mu \mathrm{g}$ of membrane protein in each lane) was followed by measurement of the fluorescence of membrane-associated tubulin with a fluorescence imaging system (Storm 840; Molecular Dynamics). The results represent one of three similar experiments performed in triplicate. Open circles, Membranes treated with $1 \mathrm{~mm}$ carbachol; filled circles, membranes treated with $1 \mathrm{~mm}$ carbachol and $30 \mu \mathrm{M}$ $\mathrm{PIP}_{2}$. B, PIP $\mathrm{P}_{2}$-assisted recruitment of tubulin- $\left[{ }^{32} \mathrm{P}\right] \mathrm{AAGTP}$ to the membrane is concentration-dependent. Membranes from Sf9 cells containing $\mathrm{m} 1$ muscarinic receptors, G $\alpha \mathrm{q}$, and PLC $\beta_{1}$ were incubated with $1 \mathrm{~mm}$ carbachol, $1 \mu \mathrm{M}$ tubulin- $\left[{ }^{32} \mathrm{P}\right]$ AAGTP, and increasing concentrations of $\mathrm{PIP}_{2}$, as described in Figure 1. After SDS-PAGE $(50 \mu \mathrm{g}$ of membrane protein in each lane) ${ }^{32} \mathrm{P}$-labeled protein bands were measured by phosphorimage analysis. One of three identical experiments done in triplicate with similar results is shown. $C$, Carbachol-evoked $\mathrm{G} \alpha \mathrm{q}$ transactivation by tubulin is not affected by $\mathrm{PIP}_{2}$. The experiments were done as described in $A$, except that tubulin-[ $\left[{ }^{32} \mathrm{P}\right]$ AAGTP was used. Proteins were resolved by $\operatorname{SDS}-\mathrm{PAGE}(50 \mu \mathrm{g}$ of membrane protein in each lane), and the radioactivity of the $\mathrm{G} \alpha \mathrm{q}$ bands $\left(\left[{ }^{32} \mathrm{P}\right] \mathrm{AAGTP}\right.$ was transferred from tubulin) was measured by phosphorimage analysis (Storm 840; Molecular Dynamics). One of five independent experiments done in triplicate with similar results is shown. Open circles, Membranes treated with $1 \mathrm{~mm}$ carbachol; filled circles, membranes treated with $1 \mathrm{~mm}$ carbachol and 30 $\mu \mathrm{M} \mathrm{PIP}_{2} . D$, The increased membrane association caused by $\mathrm{PIP}_{2}$ was not linked to $\mathrm{G} \alpha \mathrm{q}$ transactivation. The percent ratios of $\left[{ }^{32} \mathrm{P}\right] A$ AGTP-labeled $\mathrm{G} \alpha \mathrm{q}$ and tubulin-[ $\left.{ }^{32} \mathrm{P}\right] \mathrm{AAGTP}$ at the various $\mathrm{PIP}_{2}$ concentrations are derived from the experiment described in $B$. One of three identical experiments done in triplicate with similar results is shown. Control values for $B$ and $D$ represent the amount of tubulin associated with the plasma membrane in the absence of carbachol or $\mathrm{PIP}_{2}$.

\section{$\mathrm{PIP}_{\mathbf{2}}$ increases the association of tubulin with PLC $\boldsymbol{\beta}_{\mathbf{1}}$}

Because PIP $\mathrm{P}_{2}$ is the natural substrate for PLC $\beta_{1}$, the relevance of PLC $\beta_{1}$ to the process of $\mathrm{PIP}_{2}$-mediated association of tubulin with the membrane was tested. In the absence of PLC $\beta_{1}, \mathrm{PIP}_{2}$ had no effect on the association of tubulin with the $\mathrm{Sf} 9$ cell membranes (Fig. 5A). Thus, it appeared that PLC $\beta_{1}$ was involved in the $\mathrm{PIP}_{2}$-promoted membrane association of tubulin.

This was tested by coimmunoprecipitation. Tubulin coimmu- 
A

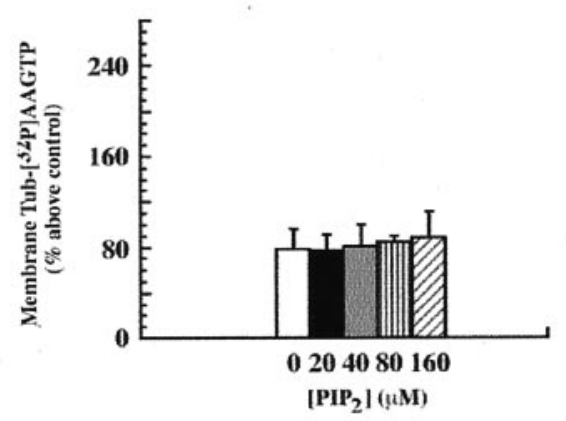

B

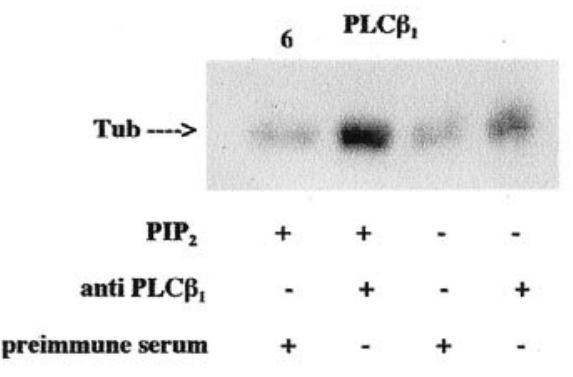

C

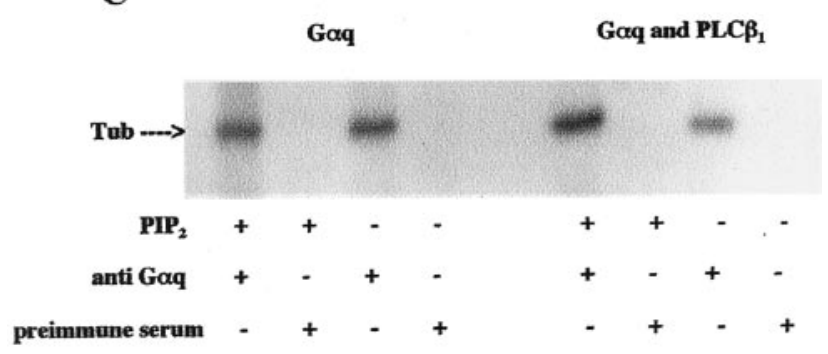

Figure 5. $\mathrm{PIP}_{2}$ is involved in the association of tubulin with PLC $\beta 1 . A$, $\mathrm{PIP}_{2}$ does not potentiate the membrane association of tubulin when PLC $\beta_{1}$ is not present. Membranes from Sf9 cells containing m1 muscarinic receptors and G $\alpha$ q but not PLC $\beta_{1}$ were incubated with tubulin- $\left[{ }^{32} \mathrm{P}\right]$ AAGTP and the indicated concentrations of $\mathrm{PIP}_{2}$ as described in Figure $4 B$. One of two identical experiments done in triplicate with similar results is shown. Tubulin associated with the membrane in the absence of carbachol represents the control. $B, \mathrm{PIP}_{2}$ increases coimmunoprecipitation of PLC $\beta_{1}$ with tubulin (Tub). Membrane preparations of Sf9 cells containing PLC $\beta_{1}$ were extracted with $1 \%$ sodium cholate. Where indicated, tubulin- $\left[{ }^{32} \mathrm{P}\right]$ AAGTP was preincubated with $\mathrm{PIP}_{2}$ as described in Materials and Methods. After UV irradiation, each sample was incubated overnight with anti-PLC $\beta_{1}$ antiserum or preimmune serum, as indicated, and immunoprecipitated as described. The immunoprecipitates were subjected to SDS-PAGE and autoradiography. An autoradiogram from one of four independent experiments with identical results is shown. $C, \mathrm{PIP}_{2}$ increased coimmunoprecipitation of G $\alpha \mathrm{q}$ and tubulin when PLC $\beta_{1}$ was present. Membrane preparations of Sf9 cells, expressing either G $\alpha \mathrm{q}$ or $\mathrm{G} \alpha \mathrm{q}$ and $\mathrm{PLC} \beta_{1}$, were tested as described in $B$, except that anti-G $\alpha \mathrm{q}$ antiserum was used to test $\mathrm{G} \alpha \mathrm{q}$ coimmunoprecipitation with tubulin. Note that $\mathrm{G} \alpha \mathrm{q}$ expression level decreased when Sf9 cells were cotransfected with G $\alpha$ q and PLC $\beta_{1}$ baculoviruses, as revealed by immunoblotting with anti-G $\alpha \mathrm{q}$ antiserum. An autoradiogram from one of three similar experiments is shown.

noprecipitates with $\mathrm{G} \alpha \mathrm{q}$ and, to a lesser extent, PLC $\beta_{1}$ (Popova et al., 1997). However, the mechanism whereby $\mathrm{PIP}_{2}$ affects these interactions has not been evaluated. Extracts from Sf9 membranes, containing PLC $\beta_{1}$, G $\alpha \mathrm{q}$, or both, were tested (Fig. $5 B, C$ ).
$\mathrm{PIP}_{2}$ increased coimmunoprecipitation of tubulin-[ $\left.{ }^{32} \mathrm{P}\right] \mathrm{AAGTP}$ with PLC $\beta_{1}$ by approximately twofold [204 $\pm 11.0 \%$ (SD)], suggesting stabilization of tubulin-PLC $\beta_{1}$ interaction (Fig. $5 B$ ). PIP 2 did not alter the coimmunoprecipitation of tubulin and $\mathrm{G} \alpha \mathrm{q}$ (Fig. $5 C$, left). However, when G $\alpha \mathrm{q}$ and PLC $\beta_{1}$ were both present on the membrane, $\mathrm{PIP}_{2}$ increased $\mathrm{G} \alpha \mathrm{q}$-tubulin coimmunoprecipitation by twofold $[216 \pm 10.0 \%$ (SD); Fig. $5 C$, right $]$. These results suggested that $\mathrm{PIP}_{2}$ might promote the formation of tubulin$\mathrm{G} \alpha \mathrm{q}-\mathrm{PLC} \beta_{1}$ complexes.

\section{Carbachol stimulation causes redistribution and colocalization of intracellular tubulin with $\mathrm{PIP}_{2}$ at the plasma membrane}

If tubulin-PIP $\mathrm{P}_{2}$ interaction modulates a related membrane signaling event, we would expect to see colocalization of tubulin and $\mathrm{PIP}_{2}$ at regions of the cell specialized for signaling. To examine this, SK-N-SH cells were transiently transfected with pEGFPtubulin. Immunofluorescence microscopy was used to confirm in vivo the microtubule depolymerization and redistribution of tubulin in SK-N-SH cells in response to carbachol stimulation. Although the appearance of the microtubules in cells treated with vehicle did not change, rapid microtubule depolymerization was observed in the carbachol-treated cells (Fig. 6).

Confocal laser immunofluorescence microscopy was used to compare the patterns of localization of tubulin and $\mathrm{PIP}_{2}$ in carbachol-treated and untreated SK-N-SH cells. A monoclonal antibody shown to bind specifically to endogenous $\mathrm{PIP}_{2}$ and to inhibit the intracellular breakdown of this phosphoinositide was used (Fukami et al., 1988). This antibody blocked the $\mathrm{PIP}_{2^{-}}$ mediated increase in tubulin binding to isolated SK-N-SH membranes. Because Lipofectin treatment compromised membrane $\mathrm{PIP}_{2}$, EGFP-tubulin-transfected cells could not be used in this study. Anti-tubulin antibody raised against the C-terminal 422 431 amino acid region of $\beta$-tubulin was used to visualize tubulin (Popova and Rasenick, 2000). In both carbachol-treated and untreated SK-N-SH cells, anti-PIP ${ }_{2}$ antibody labeling (seen in red) was detected along the cell surface and in the cytoplasm, but it was mostly enriched in the membrane and submembrane regions of the cell (Fig. 7). In the untreated cells, tubulin (seen in green) was found in microtubules, bundles, and throughout the cytoplasm. Some tubulin colocalized with $\mathrm{PIP}_{2}$ in areas close to the plasma membrane (Fig. 7A, yellow). (Note that because confocal images of cell areas that are $1 \mu \mathrm{m}$ thick are presented, filamentous microtubule arrays are not obvious.) When SK-N-SH cells were stimulated with carbachol, microtubule depolymerization and redistribution of tubulin along the plasma membrane was observed (Fig. 7B). Tubulin colocalized with $\mathrm{PIP}_{2}$ in regions along the plasma membrane. Tubulin and PIP $_{2}$ did not colocalize in areas distal to the plasma membrane in control and carbacholtreated cells. All effects of carbachol were blocked by atropine.

\section{Microtubule depolymerization inhibits phosphoinositide hydrolysis in SK-N-SH cells}

Exogenous tubulin regulates PLC $\beta_{1}$ signaling when added to membranes from engineered Sf9 or SK-N-SH neuroblastoma cells (Popova and Rasenick, 2000). To test whether endogenous tubulin affected phosphoinositide hydrolysis, SK-N-SH cells were pretreated with colchicine before analysis of inositol phosphate production. Colchicine is a well known pharmacologic agent that binds to microtubules and causes microtubule depolymerization (Wilson and Jordan, 1994). Colchicine also activates tubulin GTPase in the absence of polymerization (David-Pfeuty et al., 1979; Andreu and Timasheff, 1981). Colchicine would be ex- 


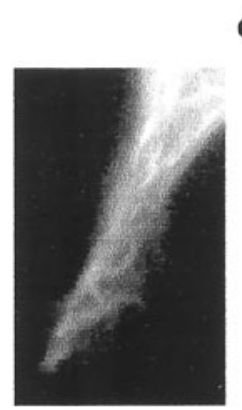

0

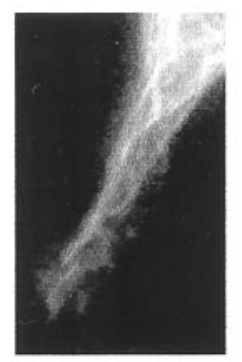

30

\section{carbachol-treated}

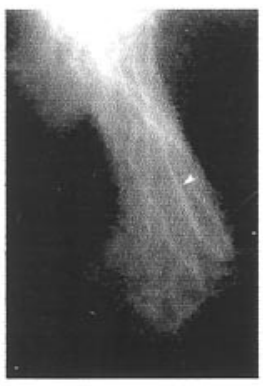

0

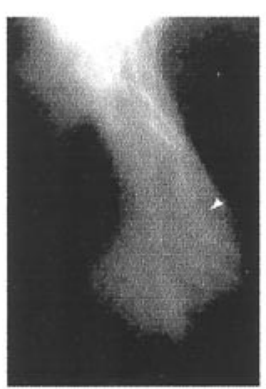

30

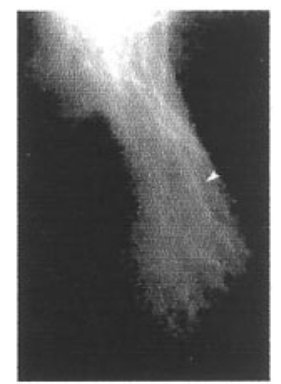

15

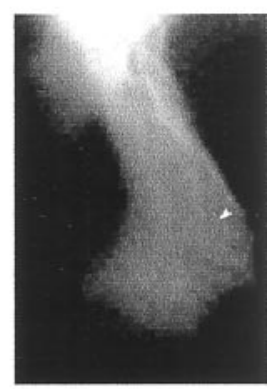

45

\section{Time (sec)}

Figure 6. Microtubule depolymerization and redistribution of tubulin in response to carbachol stimulation in GFP-tubulin-expressing SK-N-SH cells. SK-N-SH cells were transfected with EGFP-tubulin cDNA as described. Twenty four hours after transfection, cells treated with either vehicle (control) or $100 \mu \mathrm{M}$ carbachol were observed on a heated $\left(37^{\circ} \mathrm{C}\right)$ microscope stage, and images were collected at $15 \mathrm{sec}$ intervals as described. Arrowheads indicate microtubule depolymerizing in response to carbachol treatment.

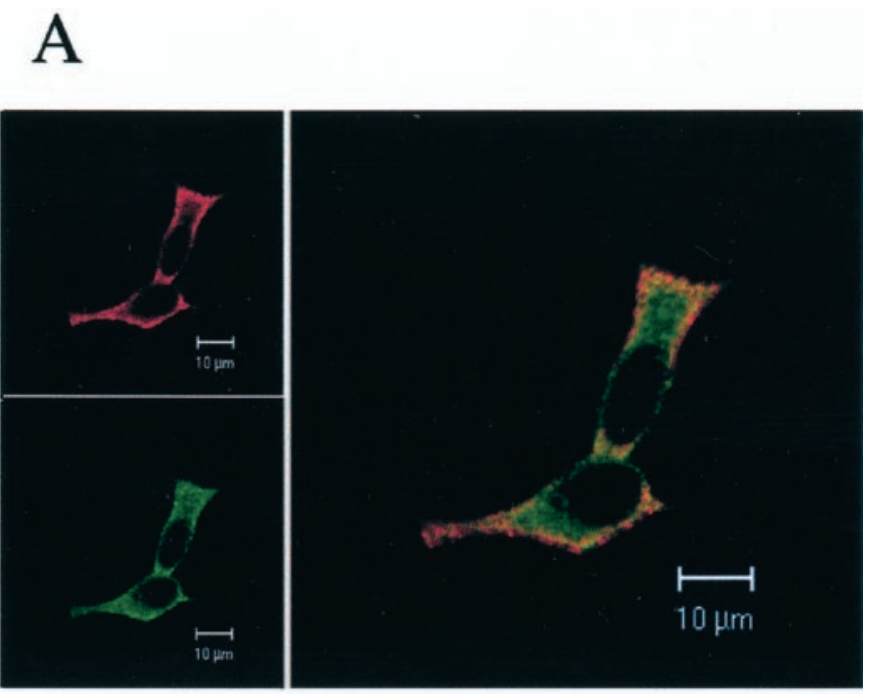

\section{B}
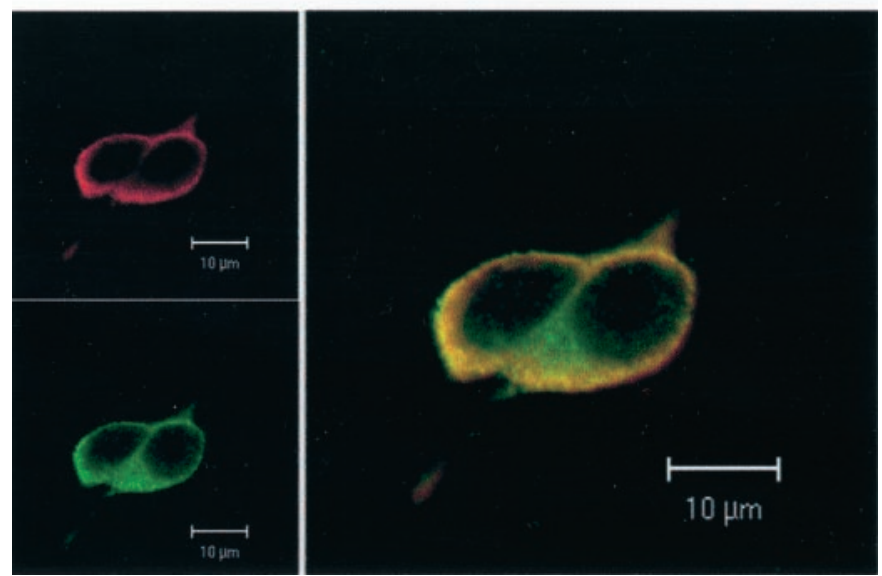

Figure 7. Carbachol stimulation causes microtubule depolymerization and translocation of tubulin to $\mathrm{PIP}_{2}$-enriched membrane regions of SK$\mathrm{N}-\mathrm{SH}$-neuroblastoma cells. Cells were untreated $(A)$ or treated with $1 \mathrm{mM}$ carbachol for $2 \mathrm{~min}(B)$ before fixation, followed by FITC labeling of tubulin and Texas Red labeling of $\mathrm{PIP}_{2}$, as described. Carbachol-induced concentration of tubulin in the $\mathrm{PIP}_{2}$-enriched membrane and submembrane areas of the cells $(B)$ is apparent. Tubulin-PIP $P_{2}$ colocalization appears in yellow. Representative images of cells obtained in one of three independent experiments with similar results are shown.

pected to increase the cellular concentration of tubulin-GDP dimers, which do not activate G $\alpha \mathrm{q}$.

Endogenous phosphoinositide pools of SK-N-SH cells were prelabeled with myo- $\left[{ }^{3} \mathrm{H}\right]$ inositol (Popova and Dubocovich, 1995), and carbachol-induced inositol phosphate generation was studied in colchicine-treated or control cells (Fig. 8). Confocal immunofluorescence microscopy demonstrated significant microtubule depolymerization in colchicine-pretreated cells (Fig. $8 A$ ). Retraction of cellular projections and change in cell shape were also observed. Colocalization of tubulin and $\mathrm{PIP}_{2}$ in regions close to the membrane was also seen.

Colchicine treatment of SK-N-SH cells inhibited carbacholstimulated inositol phosphate generation by $40 \%$ (Fig. 8B). Colchicine treatment did not affect the basal PLC activity of SK$\mathrm{N}$-SH cells. When present in the incubation medium, colchicine 
A

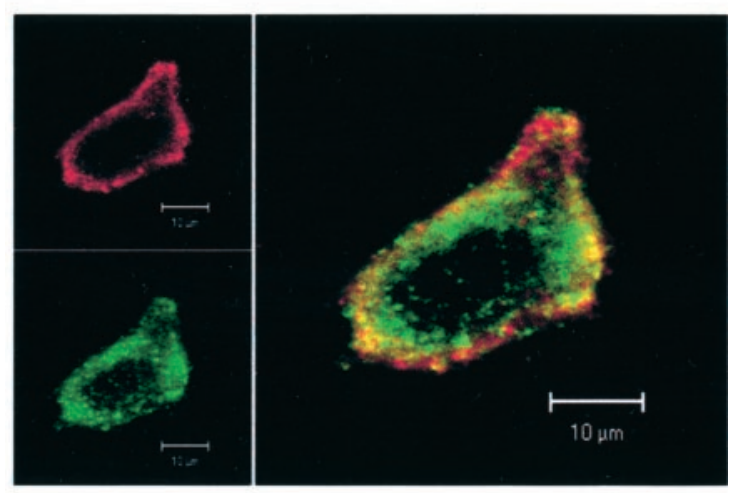

B

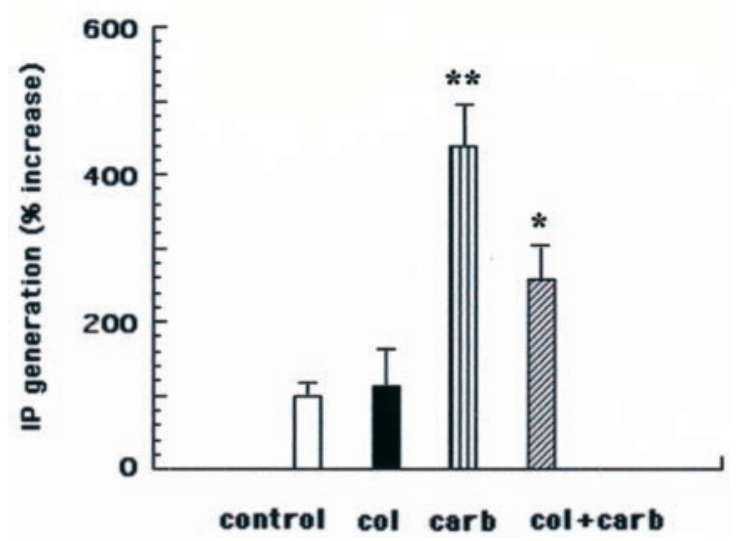

Figure 8. Colchicine-evoked microtubule depolymerization inhibits PLC $\beta$ signaling in SK-N-SH neuroblastoma cells. $A$, Confocal immunofluorescence image of an SK-N-SH cell treated for $15 \mathrm{~min}$ with $33 \mu \mathrm{M}$ colchicine as described in Materials and Methods. Microtubule depolymerization as well as colocalization (yellow) of tubulin (green) with $\mathrm{PIP}_{2}$ (red) is demonstrated. B, Myo- $\left[{ }^{3} \mathrm{H}\right]$ inositol-prelabeled SK-N-SH cells were treated for $15 \mathrm{~min}$ with $33 \mu \mathrm{M}$ colchicine $(\mathrm{col})$. Carbachol (carb; 10 $\mu \mathrm{M}$ ) was added, the samples were incubated for $30 \mathrm{~min}$ at $37^{\circ} \mathrm{C}$, and the total inositol phosphate production was measured as described. **Significantly different from control cells $(p<0.01)$; *significantly different from carbachol-treated cells $(p<0.05)$.

did not increase the association of purified tubulin with SK-N-SH membranes, suggesting that the increase in membrane-associated tubulin was attributable to the increase in tubulin dimer concentration.

Colchicine pretreatment did not affect the interaction of tubulin with $\mathrm{G} \alpha \mathrm{q}$ or PLC $\beta_{1}$. When Sf9 membranes containing these proteins were pretreated for $15 \mathrm{~min}$ with colchicine $(10 \mu \mathrm{M})$, the membrane association of $1 \mu \mathrm{M}$ tubulin-[ $\left[{ }^{32} \mathrm{P}\right] \mathrm{AAGTP}$, induced by carbachol or $\mathrm{PIP}_{2}$, was unaltered. Carbachol $(100 \mu \mathrm{M})$ and guanosine $5^{\prime}-(\beta, \gamma$-imido $)$ triphosphate $\left(\begin{array}{ll}10 & \mu \mathrm{M}\end{array}\right)$ activation of PLC $\beta_{1}$ were also unaffected when Sf9 membranes were pretreated with colchicine $\left(2.71 \pm 0.2 \mathrm{nmol} \cdot \mathrm{min}^{-1} \cdot \mathrm{mg}\right.$ of protein $^{-1}$ and $2.79 \pm 0.6 \mathrm{nmol} \cdot \mathrm{min}^{-1} \cdot \mathrm{mg}$ of protein ${ }^{-1}$ before and after colchicine, respectively).

\section{DISCUSSION}

The purpose of this study was to determine whether and how $\mathrm{PIP}_{2}$ contributes to the regulation of PLC $\beta_{1}$ signaling by tubulin. Although $\mathrm{PIP}_{2}$ is the preferred substrate for PLC $\beta_{1}$, it also binds to tubulin and shortens microtubules in vitro (Popova et al., 1997). Furthermore, low (nanomolar) concentrations of tubulin activate, whereas high (micromolar) concentrations inhibit, PLC $\beta_{1}$ (Popova et al., 1997). Tubulin binding to G $\alpha$ q, followed by transactivation of $\mathrm{G} \alpha \mathrm{q}$ attributable to the transfer of GTP from tubulin, appears responsible for the activation phase (Popova and Rasenick, 2000). The mechanism by which tubulin inhibits PLC $\beta_{1}$ had not been revealed, but it appeared to involve $\mathrm{PIP}_{2}$.

A previous study (Popova et al., 1997) speculated that, at high tubulin concentrations, association of $\mathrm{PIP}_{2}$ with tubulin might render $\mathrm{PIP}_{2}$ unavailable to PLC $\beta_{1}$ decreasing PLC $\beta_{1}$ activity. However, this previous study left open another possibility, which is that the binding of $\mathrm{PIP}_{2}$ might also affect the GTP-binding or -hydrolyzing properties of tubulin (Davis et al., 1994) and might render tubulin unable to transactivate G $\alpha \mathrm{q}$ (Popova et al., 1997). Data in Figures 1 and 2 showed that although PIP $_{2}$ interacted with tubulin in a specific manner, it did not affect either GTP binding or GTP hydrolysis by tubulin.

The present results also demonstrate that, although $\mathrm{PIP}_{2}$ had no direct effect on $\mathrm{G} \alpha \mathrm{q}$ transactivation by tubulin, it supported the membrane association of tubulin in both $\mathrm{Sf} 9$ cells, which ectopically express recombinant muscarinic receptors, $\mathrm{G} \alpha \mathrm{q}$, and PLC $\beta_{1}$, and SK-N-SH neuroblastoma cells, which normally contain these proteins (Figs. 3, 4). Colocalization of tubulin and $\mathrm{PIP}_{2}$ along the plasma membrane of SK-N-SH neuroblastoma cells was also observed (Fig. 7). These results are concordant with the idea that $\mathrm{PIP}_{2}$-enriched regions of the membrane might be sites for tubulin association. Examples of such regions are lipid rafts enriched in sphingolipids and cholesterol, which sequester certain proteins but exclude others. They are considered platforms for initiation of signal transduction processes, membrane trafficking, and molecular sorting. $\mathrm{PIP}_{2}$ is present in these rafts (Laux et al., 2000). It has been shown recently that in differentiated rat cerebellar granule cells, glycerophospholipids represent $45-75 \%$ of the constituents of sphingolipid-enriched membrane domains, of which $\mathrm{PIP}_{2}$ is $\sim 3 \%$ (Prinetti et al., 2001). Because the protein content of these domains is $\sim 0.1-2.8 \%$ (Prinetti et al., 2001), protein/PIP $\mathrm{P}_{2}$ ratios ranging between $1: 0.8$ and $1: 13.5$ are estimated. These values are concordant with the tubulin $/ \mathrm{PIP}_{2}$ ratios used in the present study. Lipid-anchored tubulin within detergent-resistant and glycolipid-enriched plasma membrane domains has also been demonstrated (Palestini et al., 2000). Thus, specific binding of tubulin to the minor membrane lipid $\mathrm{PIP}_{2}$ might facilitate tubulin targeting to such specific membrane locations.

Membrane- or phospholipid-associated tubulin has been reported (Bhattacharyya and Wolff, 1976; Klausner et al., 1981; Kumar et al., 1981; Reaven and Azhar, 1981; Regula et al., 1986; Caron and Berlin, 1987). It appeared that this "membrane" tubulin was similar to the soluble form (Bhattacharyya and Wolff, 1976; Stephens, 1977). The recently discovered microtubule depolymerization and translocation of tubulin from the cytosol to the membrane in response to receptor stimulation showed one mechanism for tubulin targeting to the membrane (Popova and Rasenick, 2000; Ciruela and McIlhinney, 2001; this study). The finding that tubulin is posttranslationally palmitoylated (Caron, 1997; Zambito and Wolff, 1997) supports this observation, be- 
cause this reversible and agonist-regulated lipid modification has been shown to facilitate association of $\mathrm{G} \alpha$ subunits with membranes (for review, see Casey, 1995; Dunphy and Linder, 1998). However, it has also been suggested that palmitoylation may be insufficient for protein targeting to the detergent-resistant membrane rafts (Melkonian et al., 1999). Additional lipid modifications or binding to additional membrane proteins or lipids may be required (Melkonian et al., 1999). Both myristoylation and palmitoylation of G $\alpha$ i may be necessary for its association with liposomes and partitioning into rafts (Moffett et al., 2000). Thus, palmitate and the binding of $\mathrm{PIP}_{2}$ might similarly cooperate to anchor tubulin dimers to specific signaling domains of the plasma membrane.

A number of studies have shown PIP $_{2}$-assisted membrane attachment of regulatory cytosolic proteins. PLC isozymes, phospholipase D, GTPases, guanine nucleotide exchange factors, GTPase-activating proteins, the vesicle-associated GTPase dynamin, and protein kinases interact with $\mathrm{PIP}_{2}$ at their pleckstrin homology (PH) domains (Musacchio et al., 1993; Shaw, 1993, 1996; Gibson et al., 1994; Hodgkin et al., 1999). The binding of $\mathrm{PIP}_{2}$ assists the targeting of these proteins to the membrane and facilitates their coupling with membrane-associated signaling molecules. Binding with high affinity to both the activated receptor and phosphoinositides was proposed to provide a multipoint attachment of $\beta$-arrestin and arrestin 3 to the plasma membrane (Gaidarov et al., 1999). Tubulin might enjoy a similar attachment.

Thus, in areas proximal to the plasma membrane, PIP $_{2}$ could support the receptor-evoked membrane attachment of tubulinGTP (Popova et al., 1997; Popova and Rasenick, 2000). The subsequent involvement of tubulin in a complex with $\mathrm{G} \alpha \mathrm{q}$ and PLC $\beta_{1}$ might stabilize their active conformation and potentiate PLC $\beta_{1}$ activation (Fig. 9A). The scenario might be quite different at high local tubulin concentrations. At high tubulin concentrations, the binding of tubulin to $\mathrm{PIP}_{2}$-rich sites of the plasma membrane proceeds in a receptor-independent manner, leading to direct association of tubulin with $\mathrm{PLC} \beta_{1}$ and subsequent enzyme inhibition (Fig. 9B). Consistent with this hypothesis is the observation that high concentrations of $\mathrm{PIP}_{2}$ decrease the interaction of tubulin with $\mathrm{G} \alpha \mathrm{q}$ and high concentrations of tubulin decrease the activity of PLC $\beta_{1}$. Tubulin-PIP - PLC $\beta_{1}$ complexes should be unable to interact with receptor-activated $\mathrm{G} \alpha \mathrm{q}$. This notion is supported by the observation that pretreatment of SK-N-SH cells with the microtubule-depolymerizing agent colchicine decreased PLC $\beta_{1}$ activation.

These regulatory mechanisms presuppose an agonistmodulated change in localized tubulin dimer concentration. Initially, hormone- or neurotransmitter-mediated activation of PLC would increase local $\mathrm{Ca}^{2+}$ concentrations, which, in turn, would cause microtubule depolymerization in this region of the cell. The resulting increase in tubulin dimer (Weisenberg, 1972; Serrano et al., 1986) might then provide a feedback inhibition of PLC $\beta_{1}$. Rapid increase in membrane-associated tubulin after carbachol treatment of cells has been demonstrated (Fig. 7; Popova and Rasenick, 2000). Furthermore, G $\alpha$ s and G $\alpha$ i have been shown to bind tubulin and activate GTPase. This destroys the GTP cap on microtubules (Roychowdhury et al., 1999) and perhaps increases local tubulin dimer concentration in response to agonist activation of G-protein-coupled receptors. The increased association of tubulin-GDP with the membrane and subsequent inhibition of PLC $\beta_{1}$ after colchicine treatment are consistent with such hypotheses (Fig. 8).

The site(s) on tubulin for specific binding of $\mathrm{PIP}_{2}$ is not yet
A

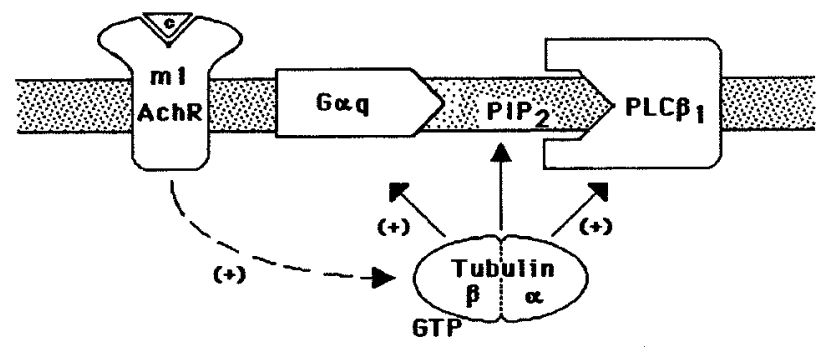

$\mathbf{B}$

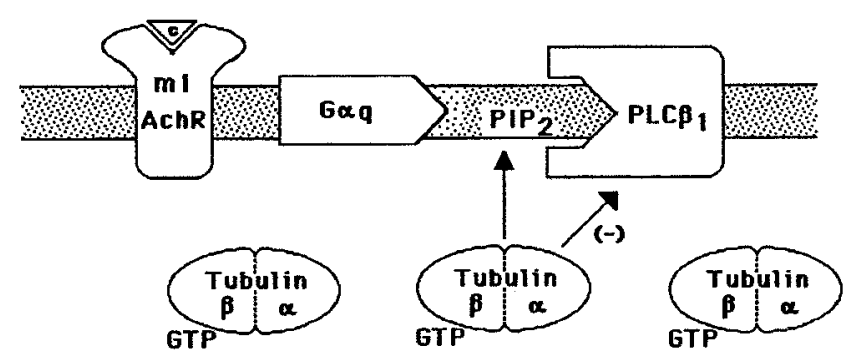

Figure 9. Mechanism of tubulin regulation of $\operatorname{PLC} \beta_{1}$ activity. $A$, Initial association of tubulin with the membrane: activation of Gq and PLC $\beta_{1}$. It is hypothesized that $\mathrm{m} 1$ muscarinic receptor stimulation triggers association of tubulin with the plasma membrane, resulting in subsequent regulation of $\mathrm{PLC} \beta_{1}$ signaling. The binding of tubulin to $\mathrm{PIP}_{2}$ at the membrane supports the membrane association of tubulin and, perhaps, the formation of the active tubulin-G $\alpha \mathrm{q}-\mathrm{PLC} \beta_{1}$ complex. $B$, Increased association of tubulin with membranes inhibits PLC $\beta_{1}$. At high local concentrations of tubulin, receptor-independent interaction of tubulin with PLC $\beta_{1}$ through PIP $P_{2}$ renders the enzyme inaccessible for receptoractivated $\mathrm{G} \alpha \mathrm{q}$, leading to $\mathrm{PLC} \beta_{1}$ inhibition. The physiological relevance of dual regulation of PLC $\beta_{1}$ by tubulin is supported by the observation that PLC $\beta_{1}$ activation increases intracellular $\mathrm{Ca}^{2+}$ concentration, which in turn causes microtubule depolymerization. Feedback inhibition of PLC $\beta_{1}$ at elevated concentrations of tubulin dimers is suggested. $m 1$ AchR, $m_{1}$ Muscarinic acetylcholine receptor.

identified. PH domains on a number of signaling molecules, including G-protein-coupled receptor kinases (GRKs), have been implicated in interacting with PIP $_{2}$ and G-protein $\beta \gamma$ subunits (Musacchio et al., 1993; Shaw, 1993, 1996; Gibson et al., 1994), but not all of them bind these ligands (Davis and Bennett, 1994). Furthermore, the G-protein-coupled receptor kinase GRK5 does not possess a PH domain and does not bind $\mathrm{G} \beta \gamma$ (Pitcher et al., 1996). However, GRK5 contains regions rich in basic amino acids within both its $\mathrm{N}$ and $\mathrm{C}$ termini (Pitcher et al., 1996), and these regions might represent lipid-binding domains (Kunapuli et al., 1994; Casey, 1995; Pronin et al., 1998). Although tubulin does not have a typical $\mathrm{PH}$ domain, it contains regions rich in basic amino acids that might be involved in the binding of $\mathrm{PIP}_{2}$. However, because other negatively charged phospholipids fail to affect tubulin polymerization, the interaction of $\mathrm{PIP}_{2}$ with tubulin appears to be specific and not solely electrostatic.

The findings described in this paper demonstrate that the specific interaction of tubulin with the integral membrane lipid and PLC $\beta_{1}$ substrate $\mathrm{PIP}_{2}$ defines its membrane association and involvement in G $\alpha \mathrm{q}$-mediated signaling. This reversible association might represent a highly localized phenomenon, whereby tubulin could temporarily attach to specific membrane domains 
for the purpose of directing G-protein-mediated signaling. This type of focal signaling, requiring local changes in calcium and microtubules, represents a continuum between G-protein signaling and the cytoskeleton.

\section{REFERENCES}

Andreu JM (1986) Hydrophobic interactions of tubulin. Ann NY Acad Sci 466:626-630.

Andreu JM, Timasheff SN (1981) The ligand- and microtubule assembly-induced GTPase activity of purified calf brain tubulin. Arch Biochem Biophys 211:151-157.

Banno Y, Nakashima T, Kumada T, Ebisawa K, Nonomura Y, Nozawa Y (1992) Effects of gelsolin on human platelet cytosolic phosphoinositidephospholipase C isozymes. J Biol Chem 267:6488-6494.

Bhattacharyya B, Wolff J (1976) Polymerisation of membrane tubulin. Nature 264:576-577.

Boguslavsky V, Rebecchi M, Morris AJ, Jhon D-Y, Rhee SG, McLaughlin S (1994) Effect of monolayer surface pressure on the activities of phosphoinositide-specific phospholipase C- $\beta 1,-\gamma 1$, and $-\delta 1$. Biochemistry 33:3032-3037.

Bradford MM (1976) A rapid and sensitive method for the quantitation of microgram quantities of protein utilizing the principle of protein-dye binding. Anal Biochem 72:248-254.

Carlier MF, Pantaloni D (1981) Kinetic analysis of guanosine 5'triphosphate hydrolysis associated with tubulin polymerization. Biochemistry 20:1918-1924.

Caron JM (1997) Posttranslational modification of tubulin by palmitoylation: I. In vivo and cell-free studies. Mol Biol Cell 8:621-636.

Caron JM, Berlin RD (1987) Dynamic interactions between microtubules and artificial membranes. Biochemistry 26:3681-3688.

Casey PJ (1995) Protein lipidation in cell signaling. Science 268:221-225.

Ciruela F, McIlhinney RA (2001) Metabotropic glutamate receptor type $1 \alpha$ and tubulin assemble into dynamic interacting complexes. J Neurochem 76:750-757.

Cote M, Payet MD, Gallo-Payet N (1997a) Association of $\alpha$ s subunit of the Gs protein with microfilaments and microtubules: implication during adrenocorticotropin stimulation in rat adrenal glomerulosa cells. Endocrinology 138:69-78.

Cote M, Payet MD, Dufour MN, Guillon G, Gallo-Payet N (1997b) Association of the $\mathrm{G}$ protein $\alpha \mathrm{q} / \alpha 11$ subunit with cytoskeleton in adrenal glomerulosa cells: role in receptor-effector coupling. Endocrinology 138:3299-3307.

David-Pfeuty T, Simon C, Pantaloni D (1979) Effect of antimitotic drugs on tubulin GTPase activity and self-assembly. J Biol Chem 254:1169611702.

Davis A, Sage CR, Dougherty CA, Farrell KW (1994) Microtubule dynamics modulated by guanosine triphosphate hydrolysis activity of beta-tubulin. Science 264:839-842.

Davis LH, Bennett V (1994) Identification of two regions of $\beta G$ spectrin that bind to distinct sites in brain membranes. J Biol Chem 269:4409-4416.

Dunphy JT, Linder ME (1998) Signalling functions of protein palmitoylation. Biochim Biophys Acta 1436:245-261.

Ferguson KM, Lemmon MA, Schlessinger J, Sigler PB (1995) Structure of the high affinity complex of inositol trisphosphate with a phospholipase C pleckstrin homology domain. Cell 83:1037-1046.

Fisher SK, Heacock AM (1988) A putative $\mathrm{M}_{3}$ muscarinic cholinergic receptor of high molecular weight couples to phosphoinositide hydrolysis in human SK-N-SH neuroblastoma cells. J Neurochem 50:984-987.

Fukami K, Matsuoka K, Nakanishi O, Yamakawa A, Kawai S, Takenawa T (1988) Antibody to phosphatidylinositol 4,5-bisphosphate inhibits oncogene-induced mitogenesis. Proc Natl Acad Sci USA 85:9057-9061.

Gaidarov I, Krupnick JG, Falck JR, Benovic JL, Keen JH (1999) Arrestin function in $\mathrm{G}$ protein-coupled receptor endocytosis requires phosphoinositide binding. EMBO J 18:871-881.

Gibson TJ, Hyvonen M, Birney E, Musacchio A, Saraste M (1994) PH domain: the first anniversary. Trends Biochem Sci 19:349-353.

Glaven JA, Zheng Y, Wu WJ, Cerione RA (1996) Phosphatidylinositol 4,5-bisphosphate provides an alternative to guanine nucleotide exchange factors by stimulating the dissociation of GDP from Cdc42Hs. J Biol Chem 271:23815-23819.

Goldschmidt-Clermont PJ, Machesky LM, Baldassare JJ, Pollard TD (1990) The actin-binding protein profilin binds to $\mathrm{PIP}_{2}$ and inhibits its hydrolysis by phospholipase C. Science $247: 1575-1578$.

Goldschmidt-Clermont PJ, Kim JW, Machesky LM, Rhee SG, Pollard TD (1991) Regulation of phospholipase $\mathrm{C} \gamma_{1}$ by profilin and tyrosine phosphorylation. Science 251:1231-1233.

Graber SG, Figler RA, Garrison JC (1992) Expression and purification of functional $\mathrm{G}$ protein $\alpha$ subunits using a baculovirus expression system. J Biol Chem 267:1271-1278.

Hodgkin MN, Masson MR, Powner D, Sagib KM, Ponting CP, Wakelam MJO (1999) Phospholipase D regulation and localisation is dependent upon a phosphatidylinositol 4,5-biphosphate-specific PH domain. Curr Biol 17:43-46.

Ibarrondo J, Joubert D, Dufour MN, Cohen-Solal A, Homburger V, Jard S, Guillon G (1995) Close association of the $\alpha$ subunits of Gq and G11 $G$ proteins with actin filaments in WRK1 cells: relation to G proteinmediated phospholipase C activation. Proc Natl Acad Sci USA 92:8413-8417.

Kavran JM, Klein DE, Lee A, Falasca M, Isakoff SJ, Skolnik EY, Lemmon M A (1998) Specificity and promiscuity in phosphoinositide binding by pleckstrin homology domains. J Biol Chem 273:3049730508 .

Klausner RD, Kumar N, Weinstein JN, Blumental R, Flavin M (1981) Interaction of tubulin with phospholipid vesicles. I. Association with vesicles at the phase transition. J Biol Chem 256:5879-5885.

Kumar N, Klausner RD, Weinstein JN, Blumenthal R, Flavin M (1981) Interaction of tubulin with phospholipid vesicles. II. Physical changes of the protein. J Biol Chem 256:5886-5889.

Kunapuli P, Gurevich VV, Benovic JL (1994) Phospholipid-stimulated autophosphorylation activates the $\mathrm{G}$ protein-coupled receptor kinase GRK5. J Biol Chem 269:10209-10212.

Laux T, Fukami K, Thelen M, Golub T, Frey D, Caroni P (2000) GAP43, MARCKS, CAP23 modulate PI(4,5)P(2) at plasmalemmal rafts, regulate cell cortex actin dynamics through a common mechanism J Cell Biol 149: 11455-11471.

Melkonian KA, Ostermeyer AG, Chen JZ, Roth MG, Brown DA (1999) Role of lipid modifications in targeting proteins to detergent-resistant membrane rafts. Many raft proteins are acylated, while few are prenylated. J Biol Chem 274:3910-3917.

Moffett S, Brown DA, Linder ME (2000) Lipid-dependent targeting of $\mathrm{G}$ proteins into rafts. J Biol Chem 275:2191-2198.

Musacchio A, Gibson T, Rice P, Thompson J, Saraste M (1993) The PH domain: a common piece in the structural patchwork of signalling proteins. Trends Biochem Sci 18:343-348.

Palestini P, Pitto M, Tedeschi G, Ferraretto A, Parenti M, Brunner J, Masserini M (2000) Tubulin anchoring to glycolipid-enriched, detergent-resistant domains of the neuronal plasma membrane. J Biol Chem 275:9978-9985.

Parker EM, Kameyama K, Higashijima T, Ross EM (1991) Reconstitutively active $G$ protein-coupled receptors purified from baculovirusinfected insect cells. J Biol Chem 266:519-527.

Pitcher JA, Fredericks ZL, Stone WC, Premont RT, Stoffel RH, Koch WJ, Lefkowitz RJ (1996) Phosphatidylinositol 4,5-bisphosphate $\left(\mathrm{PIP}_{2}\right)$-enhanced $\mathrm{G}$ protein-coupled receptor kinase (GRK) activity. Location, structure, and regulation of the $\mathrm{PIP}_{2}$ binding site distinguishes the GRK subfamilies. J Biol Chem 271:24907-24913.

Popova J, Rasenick MM (2000) Muscarinic receptor activation promotes the membrane association of tubulin for the regulation of Gq-mediated phospholipase $C \beta_{1}$ signaling. J Neurosci 20:2774-2782.

Popova J, Johnson GL, Rasenick MM (1994) Chimeric G $\alpha \mathrm{s} / \mathrm{G} \alpha \mathrm{i} 2$ proteins define domains on $\mathrm{G} \alpha$ s that interact with tubulin for $\beta$-adrenergic activation of adenylyl cyclase. J Biol Chem 269:21748-21754.

Popova JS, Dubocovich ML (1995) Melatonin receptor-mediated stimulation of phosphoinositide breakdown in chick brain slices. J Neurochem 64:130-138.

Popova JS, Garrison JC, Rhee SG, Rasenick MM (1997) Tubulin, Gq, and phosphatidylinositol 4,5-bisphosphate interact to regulate phospholipase $C \beta_{1}$ signaling. J Biol Chem 272:6760-6765.

Prinetti A, Chigorno V, Prioni S, Loberto N, Marano N, Tettamanti G, Sonnino S (2001) Changes in the lipid turnover, composition, and organization, as sphingolipid-enriched membrane domains, in rat cerebellar granule cells developing in vitro. J Biol Chem 276:21136-21145.

Pronin AN, Carman CV, Benovic JL (1998) Structure-function analysis of $\mathrm{G}$ protein-coupled receptor kinase-5. Role of the carboxyl terminus in kinase regulation. J Biol Chem 273:31510-31518.

Rasenick MM, Wang N (1988) Exchange of guanine nucleotides between tubulin and GTP-binding proteins that regulate adenylate cyclase: cytoskeletal modification of neuronal signal transduction. J Neurochem 51:300-311.

Rasenick MM, Talluri M, Dunn III WJ (1994) Photoaffinity guanosine 5 '-triphosphate analogs as a tool for the study of GTP-binding proteins. Methods Enzymol 237:100-110.

Ravindra R, Kunapuli SP, Forman LJ, Nagele RG, Foster KA, Patel SA (1996) Effect of transient overexpression of $\mathrm{Gq} \alpha$ on soluble and polymerized tubulin pools in GH3 and AtT-20 cells. J Cell Biochem 61:392-401.

Reaven E, Azhar S (1981) Effect of various hepatic membrane fractions on microtubule assembly-with special emphasis on the role of membrane phospholipids. J Cell Biol 89:300-308.

Regula CS, Sager PR, Berlin RD (1986) Membrane tubulin. Ann NY Acad Sci 466:832-842

Rhee SG, Bae YS (1997) Regulation of phosphoinositide-specific phospholipase C isozymes. J Biol Chem 272:15045-15048.

Roychowdhury S, Rasenick MM (1994) Tubulin-G protein association stabilizes GTP binding and activates GTPase: cytoskeletal participation in neuronal signal transduction. Biochemistry 33:9800-9805. 
Roychowdhury S, Panda D, Wilson L, Rasenick MM (1999) G protein $\alpha$ subunits activate tubulin GTPase and modulate microtubule polymerization dynamics. J Biol Chem 274:13485-13490.

Serrano L, Valencia A, Caballero R, Avila J (1986) Localization of the high affinity calcium-binding site on tubulin molecule. J Biol Chem 261: $7076-7081$

Shaw G (1993) Identification of novel pleckstrin homology (PH) domains provides a hypothesis for $\mathrm{PH}$ domain function. Biochem Biophys Res Commun 195:1145-1151.

Shaw G (1996) The pleckstrin homology domain: an intriguing multifunctional protein module. Bioessays 18:35-46.

Shelanski M, Gaskin F, Cantor C (1973) Microtubule assembly in the absence of added nucleotides. Proc Natl Acad Sci USA 70:765-768.

Steed PM, Nagar S, Wennogle LP (1996) Phospholipase D regulation by a physical interaction with the actin-binding protein gelsolin. Biochemistry 35:5229-5237.

Stephens RE (1977) Major membrane protein differences in cilia and flagella: evidence for a membrane-associated tubulin. Biochemistry 16:2047-2058.

Sun H-Q, Lin K-M, Yin HL (1997) Gelsolin modulates phospholipase C activity in vivo through phospholipid binding. J Cell Biol 138:811-820.

Terui T, Kahn RA, Randazzo PA (1994) Effects of acid phospholipids on nucleotide exchange properties of ADP-ribosylation factor 1. Evidence for specific interaction with phosphatidylinositol 4,5bisphosphate. J Biol Chem 269:28130-28135.

Wang N, Rasenick MM (1991) Tubulin-G protein interactions involve microtubule polymerization domains. Biochemistry 30:10957-10965.

Wang N, Yan K, Rasenick MM (1990) Tubulin binds specifically to the signal-transducing proteins, Gs $\alpha$ and Gi $\alpha 1$. J Biol Chem 265:1239-1242.

Weisenberg RC (1972) Microtubule formation in vitro in solutions containing low calcium concentrations. Science 177:1104-1105.

Wilson L, Jordan MA (1994) Pharmacological probes of microtubule function. In: Microtubules (Hyams JS, Lloyd CW, eds), pp 59-83. New York: Wiley-Liss.

Yan K, Greene E, Belga F, Rasenick MM (1996) Synaptic membrane G proteins are complexed with tubulin in situ. J Neurochem 66:1489-1495.

Yan K, Popova JS, Moss A, Shah B, Rasenick MM (2001) Tubulin stimulates adenylyl cyclase activity in C6 glioma cells by bypassing the $\beta$-adrenergic receptor: a potential mechanism of $\mathrm{G}$ protein activation. J Neurochem 76:182-190.

Zambito AM, Wolff J (1997) Palmitoylation of tubulin. Biochem Biophys Res Commun 239:650-654. 